\title{
Short-term phytoremediation effect of sugarcane for contaminated farmland on heavy metal accumulation ability along the Huanjiang River in Guangxi, China
}

\author{
Xiaofei Wang, ${ }^{1,2, a}$, Chaobing Deng ${ }^{1,2, *}$, , GuipingXu ${ }^{1, c}$, Zhen $\mathrm{Yu}^{3, \mathrm{~d}}$ \\ ${ }^{1}$ Light Industry and Food Engineering College, Guangxi University, Nanning 530004, China; \\ ${ }^{2}$ Guangxi Zhuang Autonomous Region Environmental Monitoring Center, Nanning 530028, China; \\ ${ }^{3}$ School of Environment, Guangxi University, Nanning 530004, China. \\ awangxiaofei26@163.com, bdcb715@sina.com, xuguiping@126.com, dyz2465@hotmail.com
}

\begin{abstract}
The increasing heavy metal pollution in the sugarcane soil along the Huanjiang River was caused by leakage and spills from $\mathrm{Pb}$ and $\mathrm{Zn}$ tailing dams during a flood event.A 12-month experiment was conducted in the farmland with contaminated soil to evaluate the potential of sugarcane for remediation of soil contaminated with $\mathrm{As}, \mathrm{Pb}, \mathrm{Cd}, \mathrm{Cu}$, and $\mathrm{Zn}$. Total and available heavy metal concentrations in the contaminated soils were analyzed before and after the phytoremediation application. The heavy metal concentration with phytoremediation was reduced compared with no sugarcane treatments. Elements showed low mobility, which was related to their total concentration in soil. $\mathrm{Cu}$ and $\mathrm{Zn}$ exhibited the greatest potential for release and thus for transporting to non-contaminated areas. The situation of $\mathrm{Pb}$ and $\mathrm{Cd}$ was intermediate. Heavy metal concentrations in the sugarcane juice were all below the maximum for contaminants in food, but that in bagasse met the maximum of standard. Sugarcane phytoremediation reduced the trace element availability and the risk of entry into the food chain. This technique is cheaper than other methods and proved to be a successful and reliable technique for remediation of large-scale trace element-contaminated soil with minimum maintenance.
\end{abstract}

Key Words: heavy metal, contaminated soils, Sugarcane, phytoremediation, sequential extraction.

\section{Introduction}

Heavy metal-contaminated soil has emerged as a significant environmental problem through worldwide [1, 2, 3, 4]. Irrespective of their sources in the soil, accumulated heavy metal can degrade soil quality and reduce crop yield and quality of agricultural products, and thus negatively impact the health of humans, animals, and the ecosystem [5, 6, 7]. Heavy metal accumulation in surface soils, which is considered as a chemical time bomb, may pose a potential threat to the environment and human health [8]. For example, As can affect the gastrointestinal tract, respiratory tract, skin, liver, cardiovascular, hematopoietic, and nervous systems. In addition, As can cause black foot disease and cancer risks for skin and various viscera, including the lung, bladder, kidney, and liver [6, 9]. Moreover, $\mathrm{Cr}, \mathrm{Cd}, \mathrm{Cu}, \mathrm{Pb}$, and $\mathrm{Zn}$ have been considered to be related to various 
types of cancer [7]. In contaminated farmlands, heavy metals accumulate in the edible parts of crops to levels that exceed food safety standards. These metals can enter the food chain through food production and threaten the health of animals and humans [5, 6, 7, 9, 10]. Thus, the remediation of contaminated farmland soil is dramatically importantto ensure food safety and public health.

Remediation of soils contaminated with heavy metal is mainly based either on the extraction or the stabilization of the contaminants. Physico-chemical extraction techniques generally imply a high-cost degradation of soil structure, whereas stabilization techniques can improve the physico-chemical and biological properties of soils, do not generate by-products, are less expensive, and are thus more suitable for extensive remediation [11]. These techniques are generally environmentally disruptive and expensive, and they damage the soil. The phytoremediation technology has been highlighted as a potentially reliable and cost-effective alternative to extensively reclaim areas moderately contaminated with heavy metal. This technique aims to enhance the natural attenuation mechanisms in soil (sorption, precipitation, and complexation) by establishment of plants and/or amendments to render contaminants less mobile [12, 13]. This process indicates that the vegetation cover protects the soil surface against wind and water erosion, which reduces the potential for trace element leaching and run-off transport. This technique also decreases the re-entrainment of particles that can be directly inhaled or ingested [6,11]. Plants may also facilitate the immobilization mechanisms in the rhizosphere that reduce trace element mobility. Studies on plants to stabilize heavy metal in soil have shown significantly differences in the absorption of heavy metals among varieties of the same species [10, 14, 15, 16, 17]. Selecting plant varieties with low absorption of heavy metals is important to reduce the risk of heavy metal exposure. Recent studies through worldwide have mainly focused on the use of sugarcane to remediate contaminated soil $[13,18]$. Sugarcane is a poor accumulator of some metals, such as $\mathrm{Cu}$, $\mathrm{Cd}$, and Se. When Cd content in the soil is less than $50 \mathrm{mg} \mathrm{kg}^{-1}$, the low amount accumulated in the cane juice implies that it is safe for consumption [14]. Sugarcane is also advantageous because it is perennial, and can be harvested over several years without replanting, and strongly resistant todisease. In addition, As, $\mathrm{Pb}$, and $\mathrm{Cd}$ have been identified as the major heavy metal pollutants [18]. In the standard of contaminant limit in food, the major metal and metalloid elements are $\mathrm{As}, \mathrm{Pb}, \mathrm{Cd}$, $\mathrm{Cr}$, and $\mathrm{Hg}$. Therefore, we focused on the impact of $\mathrm{As}, \mathrm{Pb}, \mathrm{Cd}, \mathrm{Cu}$, and $\mathrm{Zn}$ on sugarcane and food safety.

In this study, the effectiveness of a sugarcane with low heavy-metal accumulation (assisted natural remediation) to remediate a soil that is moderately contaminated with $\mathrm{As}, \mathrm{Cd}, \mathrm{Cu}, \mathrm{Pb}$, and Zn was assessed by the variance of heavy metal concentration. The total concentration and available forms of the trace metals in the contaminated sugarcane soil were determined. The effects of sugarcane on the trace element availability and total concentration were investigated. In addition, the relationship between the heavy metal concentration of soil and sugarcane was established through different assessment criteria. The trace metals were evaluated to have a potential for bioaccumulation in sugarcane, and the risks to human health when consuming the sugarcane juice was assessed. Sugarcane with low-level accumulation exhibited a high tolerance for contaminated soils and restored these contaminated farmland soils. The results will be extremely useful for selection strategies to use and remediate farmland contaminated with low to moderate levels of heavy metals, which is a widespread concern across southern China. 


\section{Materials and Methods}

\subsection{Study Area}

Our focal area was located in the subtropical county along the Huanjiang River, Guangxi Zhuang Autonomous Region. The soil pollution in this area was due to the leakage and spills from $\mathrm{Pb}$ and $\mathrm{Zn}$ tailing dams that were washed down the river-flooded farmlands on both sides of the lower river during a flood event. A total of 185 surface soil samples (0-0.20 m depth) were collected on rectangular sampling grids (11.6 km edge length) from an area of more than $1.1 \times 10^{5} \mathrm{~km}^{2}$ in the of Guangxi province to remediate the contaminated soil with the heavy metals. The sampling points were focused on the sugarcane soil within the $107^{\circ} 51^{\prime}-108^{\circ} 43^{\prime} \mathrm{N}$ and $24^{\circ} 44^{\prime}-24^{\circ} 33^{\prime}$ E grid.

\subsection{Sample Preparation and Chemical Analyses}

The collected soil samples were dried at $25^{\circ} \mathrm{C}$, sieved through a $2.0 \mathrm{~mm}$ nylon sieve to remove sand, gravel, and plant debris, and stored in plastic bags at room temperature. The dried soil samplewere finely powdered by an agate ball grinder and sieved to pass $0.15 \mathrm{~mm}$ nylon sieve. The powdered samples were then digested by trace metal-grade acids $\left(9.0 \mathrm{~mL}\right.$ of $\mathrm{HNO}_{3}$ and $3.0 \mathrm{~mL}$ of HF) using a Mars microwave digestion system (CEM, USA) according to EPA method 3052 (US EPA 1996). After evaporating the digestion liquids to near dryness to remove HF, the residuals were redissolved with dilute $\mathrm{HNO}_{3}$ and diluted with triple distilled water. The heavy metal concentrations in the final solutions were measured by a 7700e inductively coupled plasma-mass spectrometer (ICP-MS; Agilent, USA). The instrument was calibrated prior to each set of measurements, and $50 \mu \mathrm{g} / \mathrm{L}$ of $\mathrm{Bi}, \mathrm{In}, \mathrm{Lu}, \mathrm{Rh}$, and $\mathrm{Tb}$ was used as the internal standard. With respect to quality control and assurance, procedural blanks, standard reference materials (certified standard reference estuarine sediment NIST 1646a and Chinese standard reference soils GSS10, GSS11, and 10\% replicates of the sample load were routinely inserted in the digestion sequence. The recovery rates for the target heavy metals in the standard reference materials were reasonably good (90\%-105\%). The accuracy of the analytical methods was assessed through the Community Bureau of Reference (BCR) analysis of the soil sample.

\subsection{Analyses of Sugarcane Juice and Bagasse}

Sugarcane (var. ROC-22) was obtained from the local sugarcane field along the Huanjiang River and used in this experiment. We harvested 158 sugarcane plants in December when sugarcane matured. These sugarcane plants were uniformly mixed as one sample. Sugarcane samples were collected at the time of harvest with the aid of a stainless sharp knife. The cane stalks were rinsed with deionized water to remove dirt, then peeled, and cut to smaller sizes. The sugarcane juice was squeezed out into $500 \mathrm{~mL}$ plastic vials with the aid of a precleaned extractor and kept refrigerated until analysis. Sugarcane juice samples $(5 \mathrm{~mL})$ were digested by the addition of $15 \mathrm{~mL}$ of a mixture of concentrated $\mathrm{HNO}_{3}$ (69\%), $\mathrm{H}_{2} \mathrm{SO}_{4}$ (98\%), and $\mathrm{HClO}_{4}$ (35\%) (Merck, Darmstadt, Germany) in 5:1:1 ratio and were kept at $80{ }^{\circ} \mathrm{C}$ until a transparent solution was obtained. The digested samples were filtered through $0.45 \mu \mathrm{m}$ membrane filters, and the filtrates were diluted to $50 \mathrm{~mL}$ with distilled and deionized water. The heavy metal concentrations in the sugarcane juice and bagasse samples were estimated through ICP-MS.

\section{Results and Discussion}

\subsection{Heavy Metal Concentrations Variation}

The concentrations of $\mathrm{As}, \mathrm{Pb}, \mathrm{Cd}, \mathrm{Cu}$, and $\mathrm{Zn}$ in the contaminated sugarcane soils before and after ecological remediation, as well as the soil background values of the heavy metals, are presented in 
Table 1. The corresponding farmland soil background concentrations of $\mathrm{As}, \mathrm{Pb}, \mathrm{Cd}, \mathrm{Cu}$, and $\mathrm{Zn}$ were $9.10,16.80,0.06,18.20$, and $40.25 \mathrm{mg} / \mathrm{kg}$. The sugarcane soil pollution worsened because this area suffered from leakage and spills from $\mathrm{Pb}$ and $\mathrm{Zn}$ tailing dams that washed down the farmlands on both sides of the lower river during a flood event. The heavy metal concentrations $(\mathrm{mg} / \mathrm{kg})$ in the contaminated sugarcane soil before phytoremediation of $\mathrm{As}, \mathrm{Pb}, \mathrm{Cd}, \mathrm{Cu}$, and $\mathrm{Zn}$ varied between 11.00 and 68.00, 116.00 and 1014.00, 0.21 and 8.55, 12.00 and 55.00, and 75.00 and 1848.00, respectively, with corresponding average concentrations of 32.93, 392.15, 1.03, 29.25, and 378.67 $\mathrm{mg} / \mathrm{kg}$, respectively. Based on the mean concentration, the components in the contaminated sugarcane soils were arranged in the following decreasing order: $\mathrm{Zn}>\mathrm{Pb}>\mathrm{As}>\mathrm{Cu}>\mathrm{Cd}$. The concentrations of $\mathrm{Zn}, \mathrm{Pb}, \mathrm{As}, \mathrm{Cu}$, and $\mathrm{Cd}$ in the contaminated sugarcane soil were 9.41, 21.00, 3.62, 1.61, and 17.17 times higher than their corresponding background values. Accumulation of trace metals ( $\mathrm{Cd}, \mathrm{Pb}, \mathrm{Cu}, \mathrm{Mn}$, and $\mathrm{Zn}$ ) in the soil caused by the use of effluent irrigation represented a risk for the soil productive potential and incorporation of metals into the food chain. Similar results were obtained by on $\mathrm{Cu}$ bioaccumulation in Chinese cabbage [19].

Table 1 The contaminated sugarcane soils before and after ecological remediation

\begin{tabular}{|c|c|c|c|c|c|c|c|c|}
\hline \multirow{2}{*}{$\begin{array}{l}\text { Heavy } \\
\text { metal }\end{array}$} & \multirow{2}{*}{$\begin{array}{l}\text { Ecological } \\
\text { remediation }\end{array}$} & \multicolumn{4}{|c|}{ Concentrations（mg/kg） } & \multirow{2}{*}{ SD } & \multirow{2}{*}{$\begin{array}{l}\mathrm{CV} \\
(\%)\end{array}$} & \multirow{2}{*}{$\begin{array}{c}\text { BGV } \\
(\mathrm{mg} / \mathrm{kg})\end{array}$} \\
\hline & & Min & Max & Median & Mean & & & \\
\hline \multirow{2}{*}{ As } & Before & 11.00 & 68.00 & 30.57 & 32.93 & 13.83 & 0.42 & 9.10 \\
\hline & After & 0.01 & 55.00 & 30.00 & 31.10 & 5.05 & 0.26 & - \\
\hline \multirow{2}{*}{$\mathrm{Pb}$} & Before & 116.00 & 1014.00 & 352.96 & 392.15 & 216.08 & 0.55 & 16.80 \\
\hline & After & 14.00 & 795.00 & 345.00 & 360.10 & 173.20 & 0.53 & - \\
\hline \multirow{2}{*}{$\mathrm{Cd}$} & Before & 0.08 & 8.55 & 0.73 & 1.03 & 1.10 & 1.07 & 0.06 \\
\hline & After & 0.21 & 3.38 & 0.47 & 0.70 & 172.19 & 0.46 & \\
\hline \multirow{2}{*}{$\mathrm{Cu}$} & Before & 12.00 & 50.00 & 28.14 & 29.25 & 7.50 & 0.26 & 18.20 \\
\hline & After & 14.00 & 42.00 & 18.00 & 19.20 & 0.60 & 0.87 & \\
\hline \multirow{2}{*}{$\mathrm{Zn}$} & Before & 75.00 & 1848.00 & 341.66 & 378.67 & 258.05 & 0.68 & 40.25 \\
\hline & After & 12.00 & 1112.00 & 294.00 & 324.80 & 9.06 & 0.23 & \\
\hline
\end{tabular}

SD standard deviation, CV coefficients of variation, BGV background values before the pollution

Plants that accumulate low concentrations of trace metals in their harvestable biomass may offer a sustainable method for phytoremediation of metal contaminated sites from the contaminated soils or mineral ores. In this experiment, we selected absorption into accumulation ability might better sugarcane. In particular, the concentration of heavy metals, such as $\mathrm{Pb}$ and $\mathrm{As}$, in edible parts of a plant should be below the maximum limits for heavy metals in foods, as specified in the Chinese National Standard (GB2762-2005). Sugarcane is advantageous because it is perennial, can be harvested over several years without replanting, and is strongly resistant to disease [13, 18]. The sugarcane soil contents of $\mathrm{As}, \mathrm{Pb}, \mathrm{Cd}, \mathrm{Cu}$, and $\mathrm{Zn}(\mathrm{mg} / \mathrm{kg}$ ) after phytoremediation varied between 0.01 and 55.00, 14.00 and 795.00, 0.08 and 3.88, 12.00 and 42.00, and 12.00 and 1112.00, respectively, with corresponding average concentrations of 31.10, 360.10, 0.70, 19.20, and 324.80 $\mathrm{mg} / \mathrm{kg}$. The heavy metal concentration after sugarcane phytoremediation decreased compared with that of the untreated contaminated soils. The concentrations of $\mathrm{As}, \mathrm{Pb}, \mathrm{Cd}, \mathrm{Cu}$, and $\mathrm{Zn}$ declined to 1.82, 32.05, 0.33, 10.05, and $53.87 \mathrm{mg} / \mathrm{kg}$, respectively. Sugarcane phytoremediation was effective in altering the heavy metal concentration, particularly in the 0-20 cm depth, where the amendments were incorporated. Significant changes in the heavy metal concentration were mainly found on the surface layer, where amendments were applied and roots grew. However, the solubility and 
bioavailability of trace elements can be more important in remediation studies than the total or pseudo-total concentrations of these elements in the contaminated sugarcane soil, because they represent the most labile fractions subject to leaching as well as uptake by plant and microorganisms [20, 21].

Some plants can tolerate, remain, and survive in heavy-metal contaminated soils that are toxic for other plants. The tolerance of some species to high concentration of heavy metals may be attributed to some potential mechanisms at the cellular level [22]. Production of metallothionein (i.e., a family of cysteine-rich, low-molecular weight proteins) that bonds to metals may help plants tolerate toxic metals [22]. Thus, the concentrations of the trace elements in the experimental plot remained high despite the sugarcane phytoremediation operations. Differences in the pseudo-total trace element concentrations between treatments were not expected since trace elements cannot be degraded contrary to organic contaminants. Interactions within the soil matrix will ultimately determine whether the trace elements remain within the fraction by which they entered the soil, assuming that no redistribution of trace elements occurs during the sequential extraction.

\subsection{Available Heavy Metal Forms Variation}

A well-known BCR method of sequential extraction procedure was used to assess the relative mobility and distribution of the trace elements in soil [20,21]. The available heavy metal forms in the contaminated sugarcane soil before and after phytoremediation are shown in Table 2.

Table 2 The available heavy metal forms in the contaminated sugarcane soil before and after phytoremediation

\begin{tabular}{|c|c|c|c|c|c|c|c|c|}
\hline $\begin{array}{c}\text { Heavy } \\
\text { metal }\end{array}$ & $\begin{array}{c}\text { Ecological } \\
\text { remediation }\end{array}$ & $\begin{array}{c}\mathrm{F} 1 \\
(\mathrm{mg} / \mathrm{kg})\end{array}$ & $\begin{array}{c}\mathrm{F} 2 \\
(\mathrm{mg} / \mathrm{kg})\end{array}$ & $\begin{array}{c}\mathrm{F} 3 \\
(\mathrm{mg} / \mathrm{kg})\end{array}$ & $\begin{array}{c}\mathrm{F} 4 \\
(\mathrm{mg} / \mathrm{kg})\end{array}$ & $\begin{array}{c}\text { ATV } \\
(\mathrm{mg} / \mathrm{kg})\end{array}$ & $\begin{array}{c}\mathrm{TV} \\
(\mathrm{mg} / \mathrm{kg})\end{array}$ & $\begin{array}{c}\text { PR } \\
(\%)\end{array}$ \\
\hline \multirow{2}{*}{$\mathrm{As}$} & Before & 1.56 & 1.56 & 3.91 & 27.54 & 34.57 & 32.93 & 104.98 \\
\cline { 2 - 9 } & After & 0.44 & 1.31 & 3.94 & 25.04 & 30.73 & 31.10 & 98.81 \\
\hline \multirow{2}{*}{$\mathrm{Pb}$} & Before & 152.00 & 86.17 & 81.00 & 102.94 & 422.11 & 392.15 & 107.64 \\
\cline { 2 - 9 } & After & 84.72 & 82.00 & 77.00 & 94.00 & 337.72 & 360.10 & 93.79 \\
\hline \multirow{2}{*}{$\mathrm{Cd}$} & Before & 0.30 & 0.27 & 0.14 & 0.24 & 0.95 & 1.03 & 92.23 \\
\cline { 2 - 9 } & After & 0.28 & 0.20 & 0.10 & 0.10 & 0.68 & 0.70 & 97.14 \\
\hline \multirow{2}{*}{$\mathrm{Cu}$} & Before & 3.60 & 1.50 & 2.96 & 22.10 & 30.16 & 29.25 & 103.11 \\
\cline { 2 - 9 } & After & 1.95 & 1.54 & 2.80 & 12.50 & 18.79 & 19.20 & 97.86 \\
\hline \multirow{2}{*}{$\mathrm{Zn}$} & Before & 33.00 & 29.93 & 47.00 & 266.85 & 376.78 & 378.67 & 99.50 \\
\cline { 2 - 9 } & After & 31.97 & 26.00 & 44.43 & 210.70 & 313.1 & 324.80 & 96.40 \\
\hline
\end{tabular}

F1 (weak acid extraction fraction), F2 (reducible fraction), F3 (oxidizable fraction), F4 (residual fraction), ATV (Available total valve), TV ( total valves), PR (proportional error).

The available concentrations of $\mathrm{As}, \mathrm{Pb}, \mathrm{Cd}, \mathrm{Cu}$, and $\mathrm{Zn}$ with sugarcane phytoremediation decreased compared with untreated contaminated soils. Generally, similar results of different available forms were obtained for $\mathrm{As}, \mathrm{Pb}, \mathrm{Cd}, \mathrm{Cu}$, and $\mathrm{Zn}$ in relation to the no certified values. The weak acid extraction fraction (F1), reducible fraction (F2), oxidizable fraction (F3), and residual fraction (F4) concentration of $\mathrm{Cd}$ trace element were $0.30,0.27,0.14$, and 0.24 , respectively. Special attention was also paid to $\mathrm{F} 1$ of the sequential extraction procedure, because it represents the most labile pool and may be considered for estimating the trace element bioavailability. After sugarcane remediation, the F1, F2, F3, and F4 concentrations of Cd were $0.28,0.20,0.10$, and 0.10 , respectively. The F1, F2, F3, and F4 concentrations of $\mathrm{Cu}$ were 3.60, 1.50, 2.96, and 22.10, respectively, and the corresponding values after phytoremediation were 1.95, 1.54, 2.80, and 12.50. 
The F1, F2, F3 and F4 concentration of As were 1.56, 1.56, 3.91, and 27.54, respectively, and the corresponding values after phytoremediation were $0.44,1.31,3.94$, and 25.04. The F1, F2, F3, and F4 concentration of $\mathrm{Pb}$ were 152.00, 86.17, 81.00, and 102.94, respectively, and the corresponding values after phytoremediation were 84.72, 82.00, 77.00, and 94.00. The F1, F2, F3 and F4 concentration of $\mathrm{Zn}$ were 33.00, 29.93, 47.00, and 266.85, respectively, and the corresponding values after phytoremediation were $31.97,26.00,44.43$, and 210.70 The sum of the extracted trace elements in the soil samples from the three steps plus the residual fraction was compared with the pseudo-total concentration of the trace elements from aqua-regia digestion in soil. The percentages of recovery varied between $92.23 \%$ and $107.64 \%$ for soil samples, which indicated precise experimental results. The three-step sequential extraction procedure was also applied topure amendment samples.

Different fractions of heavy metal in the soils have distinct availabilities [20, 21]. Several differences were found among the speciation distributions of the different heavy metals, and the percentages of the different heavy metal fractions in the sugarcane soils are shown in Fig. 1.

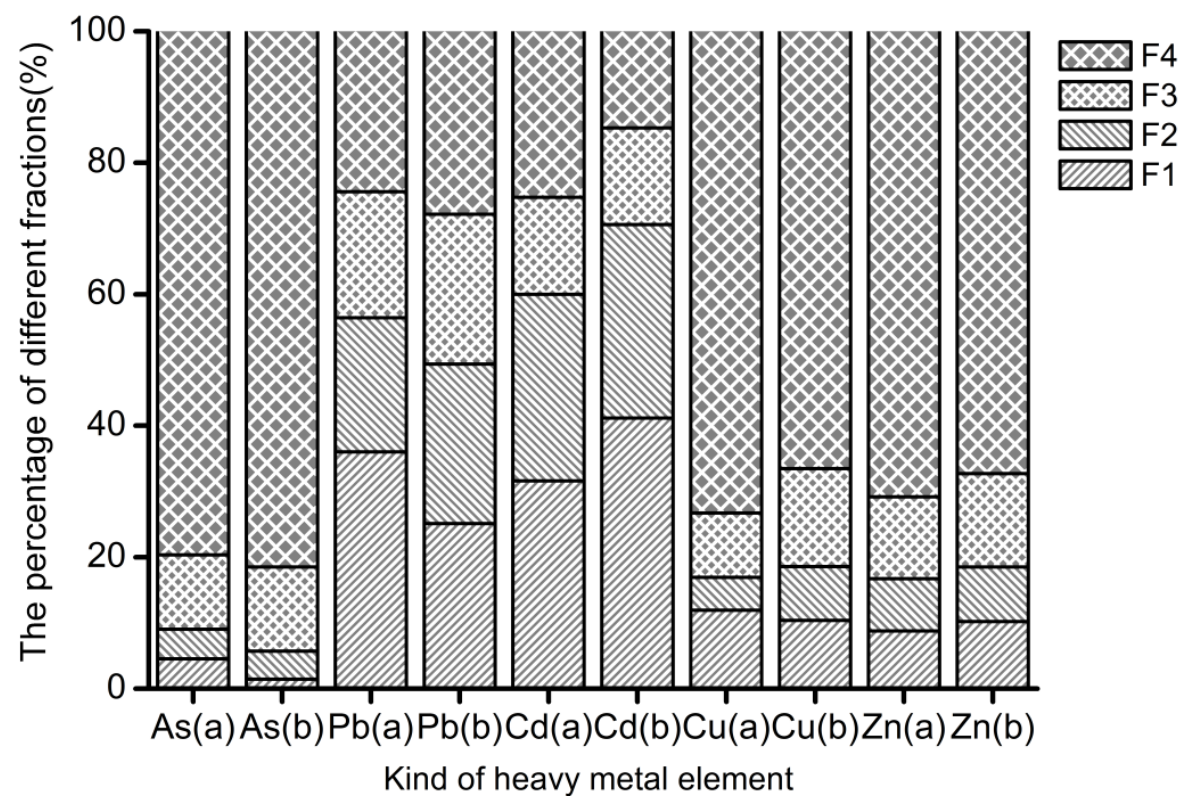

Fig. 1 The percentages of the different heavy metal fractions in the sugarcane soils are

For As, the order of the different fractions of As before sugar remediation was F4 (79.66\%) > F3 $(11.31 \%)>$ F2 (4.51\%) > F1 (4.51\%). The order of different fractions of As after sugar remediation was F4 (81.48\%) > F3 (12.82\%) > F2 (4.26\%) > F1 (1.43\%). The sum of F1, F2, and F3 accounted for significant proportions in As before and after sugarcane remediation, with mean percentages of $20.34 \%$ and $18.8 \%$, respectively. The F4 proportions of As before and after sugarcane remediation were $79.66 \%$ and $81.48 \%$, respectively. The high $\mathrm{F} 4$ results of As indicated that the residual fraction of As is unlikely to be released and with no environmental risk. Nevertheless, a potential risk still exists because of the high total concentration of As. This phenomenon is probably related to the formation of $\mathrm{Fe}$-As associations by co-precipitation after sulfide oxidation or to the role of metal oxides as the primary adsorption sites for As in most soils [23, 24]. However, none of these effects were observed, probably because of the insolubility of arsenopyrite or the rapid readsorption of soluble As by iron oxides [25]. $\mathrm{Cu}$ and $\mathrm{Zn}$ had similar fraction distributions in the three sampled soils. The sum of F1, F2, and F3 accounted for significant proportions in Cu and Zn before and after sugarcane remediation, with corresponding values of $26.72 \%$ and $33.48 \%$ before the treatment and 
29.18\% and 32.71\% after the treatment. The corresponding F4 proportions in $\mathrm{Cu}$ and $\mathrm{Zn}$ element before sugarcane remediation were $73.28 \%$ and $66.56 \%$, whereas those after phytoremediation were $70.82 \%$ and $67.29 \%$, respectively. The total concentration of $\mathrm{Cu}$ was slightly above the background value for Guangxi. These results indicated that $\mathrm{Cu}$ and $\mathrm{Zn}$ pose persistent threat to the ecosystem and plants, which can be partly attributed to the formation of very stable complexes of $\mathrm{Cu}$ [19]. A positive correlation was found between $\mathrm{Cu}$ concentrations in this fraction and the total organic $\mathrm{C}$ element. The percentage of recovery for $\mathrm{Cu}$ in this fraction was higher than those of the other elements. Although most of the $\mathrm{Cu}$ from the spill entered the soil in the soluble phase in the form of sulfates, an important amount of $\mathrm{Cu}$ was also recovered in the residual fraction [26]. This mineral shows high resistance to weathering because of its encapsulation with silicate grains, thus avoiding dissolution processes [22, 26, 27]. The mean concentrations of $\mathrm{Zn}$ in F1 were much higher than those of other elements with similar pseudo-total concentrations to As and $\mathrm{Pb}$. In fact, $\mathrm{Zn}$ is knownto be readily mobile relative to other metals [26]. No significant differences among treatments were found in the residual fraction.As a rule, the fractionation scheme showed that the trace elements studied were mainly associated with the residual pool, presumably because of the recovery of the metal sulfides from the mine spill within this fraction [22, 27]. For $\mathrm{Pb}$ and $\mathrm{Cd}$ element before and after sugarcane remediation, the sum of F1, F2, and F3 accounted for the corresponding significant proportions of $75.61 \%$ and72.17\% prior to remediation and $74.74 \%$ and 85.29\% after remediation. The $\mathrm{F} 4$ proportions in $\mathrm{Pb}$ and $\mathrm{Cd}$ before sugarcane remediation were $24.39 \%$ and $27.83 \%$, respectively, and the corresponding values after remediation were $25.26 \%$ and $14.71 \%$. The low F4 results of $\mathrm{Pb}$ and $\mathrm{Cd}$ indicated that the residual fraction of element is likely to be released and with high environmental risk. $\mathrm{Pb}$ and $\mathrm{Cd}$ are highly bioavailable and easily circulated in the food chain, thus threatening human health and environment. This fact indicated that other effective measures should be undertaken to decrease the pollution. Compared with As and $\mathrm{Pb}$ before sugarcane remediation, the sum of F1, F2, and F3 of As and Pb element decreased, contrary to the increase in F4 proportions. The sums of F1, F2, and F3 for Cd, Cu, and Zn increased, but F4 proportion decreased, after sugarcane remediation compared with those under no remediation. The distribution of $\mathrm{Pb}$ and $\mathrm{Cd}$ in the soil was clearly affected by the sugarcane phytoremediation. The recovery of $\mathrm{Pb}$ within this fraction was small. $\mathrm{Pb}$ is known to have low mobility, and thus it may have rapidly changed into less soluble forms. The distribution of $\mathrm{Pb}$ was very similar to that of $\mathrm{Cd}$. Further redistribution of $\mathrm{Pb}$ and $\mathrm{Cd}$ within the soil matrix may have removed $\mathrm{Pb}$ and $\mathrm{Cd}$ to the residual pool. The residual fraction accounts for the most recalcitrant forms of metals with negligible mobility [20, 28].

\subsection{Heavy Metal Concentration Relationship Between Soil and Sugarcane}

Sugarcane can be a phytoremediator species because of its outstanding biomass production. The different concentrations of trace metals in the sugarcane juice (Table 3) showed that all the studied metals accumulated in the sugarcane juice. 
Table 3 The different concentrations of trace metals in the sugarcane juice

\begin{tabular}{|c|c|c|c|c|c|c|c|}
\hline \multirow{2}{*}{$\begin{array}{l}\text { Heavy } \\
\text { metal }\end{array}$} & \multicolumn{4}{|c|}{ Concentrations（mg/kg） } & \multirow{2}{*}{$\begin{array}{c}\text { Standard } \\
\text { contaminant limit }\end{array}$} & \multirow{2}{*}{ Standard } & \multirow{2}{*}{$\begin{array}{l}\text { Qualifiec } \\
\text { rate }\end{array}$} \\
\hline & Min & Max & Median & Mean & & & \\
\hline As & 0.001 & 0.012 & 0.005 & 0.005 & $\leq 0.05$ & GB2762-2005 & $96.9 \%$ \\
\hline $\mathrm{Pb}$ & 0.001 & 0.117 & 0.027 & 0.032 & $\leq 0.05$ & GB2762-2005 & $93.8 \%$ \\
\hline $\mathrm{Cd}$ & 0.015 & 0.203 & 0.069 & 0.077 & $\leq 0.05$ & GB2762-2005 & $85.8 \%$ \\
\hline $\mathrm{Cu}$ & 0.065 & 0.481 & 0.145 & 0.159 & $\leq 10$ & GB15199-1994 & $100 \%$ \\
\hline $\mathrm{Zn}$ & 1.850 & 22.690 & 7.438 & 8.071 & $\leq 30$ & GB13106-1991 & $100 \%$ \\
\hline
\end{tabular}

The As concentration in sugarcane juice varied and ranged from $0.001 \mathrm{mg} \mathrm{kg}^{-1}$ to $0.012 \mathrm{mg} \mathrm{kg}^{-1}$. The mean concentration of As was $0.005 \mathrm{mg} / \mathrm{kg}$. The standard of contaminant limit in food (GB2762-2005) does not mention the limit of As in sugar cane juice; thus, the limit of As in fruit $\left(0.05 \mathrm{mg} \mathrm{kg}^{-1}\right)$ was chosen as the reference standard. The qualified rate of As concentration reached 96.9\%. The As concentration in sugarcane juice was lower than this limit in fruit and met the reference standard. The $\mathrm{Pb}, \mathrm{Cu}$, and $\mathrm{Zn}$ concentrations in the sugar cane juice varied and ranged from $0.001 \mathrm{mg} \mathrm{kg}^{-1}$ to $0.117 \mathrm{mg} \mathrm{kg}^{-1}, 0.065 \mathrm{mg} \mathrm{kg}^{-1}$ to $0.481 \mathrm{mg} \mathrm{kg}^{-1}$, and $1.850 \mathrm{mg} \mathrm{kg}^{-1}$ to 22.690 $\mathrm{mg} \mathrm{kg}^{-1}$, respectively. The mean concentrations of $\mathrm{Pb}, \mathrm{Cu}$, and $\mathrm{Zn}$ in sugar cane juice were 0.032 , 0.159 , and $8.071 \mathrm{mg} \mathrm{kg}^{-1}$. The qualified rate of $\mathrm{Pb}$ in sugarcane juice reached $93.8 \%$. The $\mathrm{Cu}$ and $\mathrm{Zn}$ concentrations in sugarcane juice were lower than this limit and met the reference standard. Significant differences were found in the $\mathrm{Cd}$ concentrations in the sugarcane juice. The Cd concentration in sugarcane juice ranged from $0.015 \mathrm{mg} \mathrm{kg}^{-1}$ to $0.203 \mathrm{mg} \mathrm{kg}^{-1}$. The mean concentration of Cd was $0.077 \mathrm{mg} \mathrm{kg}^{-1}$. The qualified rate of Cd concentration reached $85.8 \%$. The $\mathrm{Cd}$ concentrations in sugarcane juice were higher than this lower limit. The trace element concentrations in the sugarcane juice had the following ranking pattern: $\mathrm{Zn}>\mathrm{Cu}>\mathrm{Cd}>\mathrm{Pb}>\mathrm{As}$. The present results showed the low trace metal concentration of sugarcane juice. The exceeding level of trace metals in the juice extract may also be caused by the direct wet and dry depositions of pollutants on soil and foliage, which can hardly be ignored as possible sources of the metals in the sugarcane plant juice and consequently sugar.

The heavy metal concentration and qualified rate in the sugarcane bagasse are shown in Table 4.

Table 4 The heavy metal concentration and qualified rate in the sugarcane bagasse

\begin{tabular}{|c|c|c|c|c|c|c|c|}
\hline \multirow{2}{*}{$\begin{array}{c}\text { Heavy } \\
\text { metal }\end{array}$} & \multicolumn{3}{|c|}{ Concentrations $(\mathrm{mg} / \mathrm{kg})$} & $\begin{array}{c}\text { Standard contaminant } \\
\text { limit }\end{array}$ & Standard & $\begin{array}{c}\text { Qualified } \\
\text { rate }\end{array}$ \\
\cline { 2 - 5 } & Min & Max & Median & Mean & $\leq 10$ & GB13078-2001 & $100 \%$ \\
\hline $\mathrm{As}$ & 0.020 & 0.152 & 0.055 & 0.060 & $\leq 8$ & GB13078-2001 & $100 \%$ \\
\hline $\mathrm{Pb}$ & 0.300 & 7.120 & 1.782 & 2.063 & $\leq 0.5$ & GB13078-2001 & $100 \%$ \\
\hline $\mathrm{Cd}$ & 0.096 & 0.960 & 0.360 & 0.378 & - & - & - \\
\hline $\mathrm{Cu}$ & 0.806 & 4.176 & 1.510 & 1.706 & - & - & - \\
\hline $\mathrm{Zn}$ & 10.300 & 68.900 & 29.842 & 31.385 & & & - \\
\hline
\end{tabular}

The As concentration in the sugarcane bagasse varied and ranged from $0.020 \mathrm{mg} \mathrm{kg}^{-1}$ to $0.152 \mathrm{mg}$ $\mathrm{kg}^{-1}$. The mean concentration of As was $0.060 \mathrm{mg} / \mathrm{kg}$. The As concentration was remarkably low in the bagasse. The $\mathrm{Pb}, \mathrm{Cd}, \mathrm{Cu}$, and $\mathrm{Zn}$ concentrations in the sugarcane bagasse ranged from $0.300 \mathrm{mg}$ $\mathrm{kg}^{-1}$ to $7.120 \mathrm{mg} \mathrm{kg}^{-1}, 0.096 \mathrm{mg} \mathrm{kg}^{-1}$ to $0.960 \mathrm{mg} \mathrm{kg}^{-1}, 0.806 \mathrm{mg} \mathrm{kg}^{-1}$ to $4.176 \mathrm{mg} \mathrm{kg}^{-1}$, and 10.300 
$\mathrm{mg} \mathrm{kg}^{-1}$ to $68.900 \mathrm{mg} \mathrm{kg}^{-1}$, respectively. The mean concentrations of $\mathrm{Pb}, \mathrm{Cd}, \mathrm{Cu}$ and $\mathrm{Zn}$ in the bagasse were $2.063,0.378,1.706$, and $31.385 \mathrm{mg} \mathrm{kg}^{-1}$, respectively. The order of trace metal concentration in the bagasse was $\mathrm{Zn}>\mathrm{Pb}>\mathrm{Cu}>\mathrm{Cd}>\mathrm{As}$. The qualified rate of trace metal concentration reached $100 \%$. These values were all lower than the maximum level of contaminants in foods, according to the Chinese National Standard (GB13078-2001). The sugarcane was therefore considered safe because the levels of $\mathrm{As}, \mathrm{Pb}, \mathrm{Cd}, \mathrm{Cu}$, and $\mathrm{Zn}$ were below the maximum limits.

The heavy metal concentration of sugarcane was unaffected by the corresponding heavy metal concentration in the rhizosphere soil. The results from the correlation analysis between the heavy metal concentrations in the sugarcane and the rhizosphere soil are shown in Table 5.

Table 5 The correlation analysis between the heavy metal concentrations in the sugarcane and the rhizosphere soil

\begin{tabular}{|c|c|c|c|}
\hline Heavy metal & Translocation factor & Enrichment coefficient & Correlation coefficient \\
\hline $\mathrm{As}$ & 0.18 & 0.13 & 0.998 \\
\hline $\mathrm{Pb}$ & 0.28 & 0.14 & 0.348 \\
\hline $\mathrm{Cd}$ & 0.25 & 0.23 & 0.483 \\
\hline $\mathrm{Cu}$ & 0.23 & 0.13 & 0.738 \\
\hline $\mathrm{Zn}$ & 0.32 & 0.30 & 0.337 \\
\hline
\end{tabular}

Transfer factor (TF) describes the amount of an element expected to enter a plant from its substrate, under equilibrium conditions. This theory assumes a linear relationship between the concentrations of a certain element in the plant with that in the soil. An approach based on soil-plant transfer factor provides an uncomplicated and helpful method for assessing uptake of trace metals for the purposes of assessment and testing. To portray quantitatively the transfer of an element from soil to plant, the soil-plant Transfer Factor of Concentration Ratio that expresses the ratio of contaminant concentration in plant parts to concentration in dry soil is used [29, 30, 31, 32]. Transfer factor concept is the presence of a statistically significant relationship between the concentration of a given element in the soil and plant [33]. The TF was calculated as the ratio of the trace metal content in the plant or a part of plant to that in the soil. The TF values for As, $\mathrm{Pb}, \mathrm{Cd}$, $\mathrm{Cu}$, and $\mathrm{Zn}$ in sugarcane plant are shown in Table 5, which estimates the TF values of the different heavy metals from soil to sugarcane. The TF values varied greatly among the different trace metals. The TF values of $\mathrm{As}, \mathrm{Pb}, \mathrm{Cd}, \mathrm{Cu}$, and $\mathrm{Zn}$ in the sugarcane from contaminated soil were $0.18,0.28$, $0.25,0.23$, and 0.32 , respectively. The lower TF value of As may have been caused by the weak absorption of nutrients by the plant roots that were damaged by As contamination [22, 23]. Higher $\mathrm{TF}$ values were found for $\mathrm{Cu}, \mathrm{Cd}, \mathrm{Pb}$, and $\mathrm{Zn}$ from contaminated soil to sugarcane, because these metals are more portable in nature. The higher TF values for $\mathrm{Cu}, \mathrm{Cd}, \mathrm{Pb}$, and $\mathrm{Zn}$ from soil to crop showed a strong accumulation of trace elements by sugarcane. Trace metals present in the soil are absorbed by plants to either sufficient or phytotoxic levels [26]. Internal concentrations of Cd and $\mathrm{Zn}$ were more influenced by the soil/environment than by the variety of sugarcane, while the distribution of metals in plant parts was quite consistent. Approximately $77 \%$ of $\mathrm{Cd}$ and $56 \%$ of $\mathrm{Zn}$ were contained in the stem [22].

Low enrichment coefficients (ECs) of $\mathrm{As}, \mathrm{Pb}$, and $\mathrm{Cu}$ were found in the sugarcane. The $\mathrm{EC}$ is an important index for assessing the ability of plants to absorb heavy metals. This parameter is defined as the ratio of the heavy metal concentration in the sugarcane to the corresponding heavy metal 
concentration in the rhizosphere soil. The EC value of As was 0.13 . Although sugarcane has a huge biomass, it cannot extract large amounts of heavy metals from the contaminated soil because of a low EC. High concentrations of $\mathrm{Pb}$ soil reduced the uptake of the sugarcane of most other nutrients because of the damaged root. Barzegar et al. reported that $\mathrm{Cd}$ accumulated in bagasse and $\mathrm{Pb}$ primarily accumulated in bagasse and molasses [34]. Consequently, the levels of these trace metals in sugarcane juice are lower at the uncontaminated site. The present results agree with those of previous studies.

The correlation coefficients (CC) between the heavy metal concentrations in the sugarcane and in the rhizosphere soil are shown in Table 5. The CCs of $\mathrm{As}, \mathrm{Pb}, \mathrm{Cd}, \mathrm{Cu}$, and $\mathrm{Zn}$ were 0.998, 0.348, $0.483,0.738$, and 0.337 , respectively. The heavy metal concentration of sugarcane did not correlate significantly with the corresponding concentration in the rhizosphere soil. This result indicated that the heavy metal concentration in the sugarcane depends on the enrichment ability of sugarcane.

Understanding the underlying mechanisms of soil-amendment-plant interactions is necessary for the successful reclamation of contaminated sugarcane soil. At present, very little information about natural phytoremediation experiments in sugarcane regions is available. Despite the high concentrations of As in the sugarcane soil, the sugarcane did not show high levels of these elements in their tissues. The As level greatly exceeded the normal values in soils and has no known function in plants. Nevertheless, the concentration of As in the sugarcane was only above the detection limit of the method. This finding can be related to the low availability of As in soils, which is even lower at more acid $\mathrm{pH}$ values. Furthermore, As has a comparatively low soil-plant transfer coefficient because of its low mobility in the soil. $\mathrm{Pb}$ did not reach phytotoxic levels in sugarcane. The concentrations in sugarcane were below the detection limit of the method used. The low concentrations of $\mathrm{Pb}$ found in most samples could be due to the low solubility of this element at $\mathrm{pH}$ levels above 4 or to the increased TOC content, which can bind Pb strongly [35, 36]. Moreover, translocation to shoots tends to be greatly limited, although sugarcane can accumulate $\mathrm{Pb}$ in their roots. Sugarcane can tolerate a relatively high concentration of Cd in soils. However, accumulation of large quantities of $\mathrm{Cd}$ in plant tissues may result in harmful effects on animals feeding on these plants. Therefore, Cd should be carefully monitored. The Cd concentration in sugarcane was only above the detection limit of the method. The Cd concentration of the contaminated soil decreased because of the adsorption by sugarcane. Thus, sugarcane-assisted remediation can be an effective measure in reducing $\mathrm{Cd}$ concentration. The concentrations of $\mathrm{Cu}$ and $\mathrm{Zn}$ in sugarcane were lower than the standard contaminant limit. The concentration of $\mathrm{Cu}$ and $\mathrm{Zn}$ were generally below the phytotoxic range for sugarcane. The $\mathrm{Cu}$ concentration in sugarcane was low. These results could be related to the presence of other cations, such as $\mathrm{Zn}$, which could inhibit $\mathrm{Cu}$ adsorption at the root [22]. Concentrations of $\mathrm{Zn}$ in plants in the contaminated soil were higher than those of other trace elements. The utilization of a fraction at ion procedure may be a useful tool to assess the relative mobility and potential environmental hazard of trace elements in soil. This procedure may also provide useful information for future prediction of trace element mobilization. The establishment of sugarcane cover was effective in altering the soil $\mathrm{pH}$, particularly in the $0-20 \mathrm{~cm}$ depth, where the remediation were incorporated.

\section{Conclusion}

Trace heavy metal concentration in sugarcane soil was highly influenced by the origin of the contamination. The sugarcane soil pollution worsened because this area was affected by the leakage and spills from $\mathrm{Pb}$ and $\mathrm{Zn}$ tailing dams that washed down the farmlands on both sides of the lower river during a flood event. The heavy metal concentration with phytoremediation decreased 
compared those in soils without sugarcane treatments. However, sugarcane farmland soils along the Huanjiang River still present high contamination. The extractability depends on the nature of the element, and hence diverse potential environmental risks were found. The low mobility of As was related to its total concentration in soil, whereas $\mathrm{Cu}$ and $\mathrm{Zn}$ exhibited the greatest potential for release and thus for transport to non-contaminated areas. The situation of $\mathrm{Pb}$ and $\mathrm{Cd}$ was intermediate. However, low concentrations of $\mathrm{Cd}$ in plants may have toxic effects for livestock; therefore, it may pose a greater hazard for the food chain. The heavy metal concentration in sugarcane juice and bagasse could meet the lower limit standard. The sugarcane phytoremediation of a plant cover was effective in changing heavy metal concentration where amendments were applied and where roots grew. Sugarcane phytoremediation reduces trace element availability and thus the risk of entry in the food chain. This technique is cheaper than other methods and is accepted by Chinese law. Sugarcane can modify the contaminated habitat and reduce trace elements mobility. Middle and long-term evolution of the low-accumulation heavy metal formed between sugarcane and trace elements is of utmost importance. Sugarcane phytoremediation proved to be a successful and reliable technique for large-scale remediation of a trace element-contaminated soil with minimum maintenance. However, monitoring contaminated soil and sugarcane is required to ensure trace element stabilization and evaluate the need for further applications.

\section{Acknowledgement}

This work was supported by Natural Science Foundation of Guangxi (2015GXNSFEA139001), Development Project of the Guangxi Zhuang Autonomous Region Science and Technology Department (14125001-2-1).

\section{References}

[1] Manta D, Angelone M, Bellanca A, Neri R, Sprovieri M. 2002. Heavy metals in urban soils: a case study from the city of Palermo (Sicily), Italy. Sci Total Enviro 300: 229-243.

[2] Hu Y N, Liu X P, Bai J M, Shih K M, Zeng E Y, Cheng H F. 2013. Assessing heavy metal pollution in the surface soils of a region that had undergone three decades of intense industrialization and urbanization. Environ SciPollut Res 20: 6150-6159.

[3] Takashi F, Hidetaka T. 2014. Pollution distribution of heavy metals in surface soil at an informal electronic-waste recycling site. Environ Geochem Health 36: 159-168.

[4] Benhaddy L M, Hadjel M. 2014. Spatial distribution and contamination assessment of heavy metals in surface soils of HassiMessaoud, Algeria. Environ Earth Sci 71: 1473-1486.

[5] Sekhar K C, Chary N S, Kamala C T, Vairamani M, Anjaneyulu Y, Balaram V, Sorlie J E. 2006. Risk communications: around the world-environmental risk assessment studies of heavy metal contamination in the industrial area of Kattedan, India a case study. Hum Ecol Risk Assess 12: 408-422.

[6] Lin M C, Liao C M. 2008. Assessing the risks on human health associated with inorganic arsenic intake from groundwater-cultured milkfish in southwestern Taiwan. Food ChemToxicol 46: 701-709.

[7] Wang L J, Lu X W, Ren C H, Li X X, Chen C C. 2014. Contamination assessment and health risk of heavy metals in dust from Changqing industrial park of Baoji, NW China. Environ Earth Sci 71: 2095-2104.

[8] Stigliani W M, Doelman P, Salomons W, Schulin R, Smidt G R B, Seatm V D Z. 1991. Chemical time bombs-predicting the unpredictable. Environment 33: 4-30. 
[9] Rmalli S W A, Harrington C F, Ayub M, Haris P I. 2005. A biomaterial based approach for arsenic removal from water. J Environ Monit7: 279-282.

[10] Kurz H, Schulz R, Romheld V. 1999. Selection of cultivars to reduce the concentration of cadmium and thallium in food and fodder plants. J Plant Nutr Soil Sci 162: 323-328.

[11] Adriano D C, Wenzel W W, Vangronsveld J, Bolan N S. 2004. Role of assisted natural remediation in environmental cleanup. Geoderma 122, 121-142.

[12] Liu W T, Zhou Q X, An J, Liu Y B, Liu R. 2010. Variations in cadmium accumulation among Chinese cabbage cultivars and screening for Cd-safe cultivars. J Hazard Mater 173: 737-743.

[13] Wang X L, Chen T B, Lei M, Li X X, Chen C C. 2012. Selection of sugar cane varieties with a low heavy metal accumulation ability for the ecological remediation of contaminated farmland. $\mathrm{J}$ ResourEcol 3: 373-378.

[14] Wang K R. 2002. Tolerance of cultivated plants to cadmium and their utilization in polluted farm land soils. Acta Biotechnol 22: 189-198.

[15] Tiryakioglu M, Eker S, Ozkutlu F, Husted S, Cakmak I. 2006. Antioxidant defense system and cadmium uptake in barley genotypes differing in cadmium tolerance. J Trace Elem Med Bio 20: 181-189.

[16] Zhu C, Luan Z, Wang Y, Shan X. 2007. Removal of cadmium from aqueous solutions by adsorption on granularred mud (GRM). Sep PurifTechnol 57: 161-169.

[17] Liu W T, Zhou Q X, Liu Y B, Liu R. 2009. Identification of Chinese cabbage genotypes with low cadmium accumulation for food safety. Environ Pollut 157: 1961-1967.

[18] Corbi J J, Froehlich C G, Trivinho-Strixino S, Dos-Santos A. 2011. Evaluating the use of predatory insects as bioindicators of metals contamination due to sugarcane cultivation in neotropical streams. Environ Monit Assess 177: 545-554.

[19] Li X L, Shen Z G, Wai W H, Li Y S. 2001. Chemical forms of Pb, Zn and Cu in the sediment profiles of the Pearl River Estuary. Mar Pollut Bull 42: 215-223.

[20] Rauret G, López-Sanchez J F, Sahuquillo A, Rubio R, Davidson C, Ure A, Quevauliller P H. 1999. Improvement of the BCR three step sequential extraction procedure prior to the certification of the new sediment and soil reference materials. J Environ Monit 1: 57-61.

[21] Massas I, Kalivas D, Ehaliotis C, Gasparatos D. 2013. Total and available heavy metal concentrations in soils of the Thriassio plain (Greece) and assessment of soil pollution indexes. Environ Monit Assess 185: 6751-6766.

[22] Madejo'n P, Murillo J M, Marano'n T, Cabrera F, Lo'pez R. 2002. Bioaccumulation of As, Cd, $\mathrm{Cu}, \mathrm{Fe}$ and $\mathrm{Pb}$ in wild grasses affected by the aznalcollar mine spill (SW Spain). Sci Total Enviro 290: 105-120.

[23] Voigt D E, Bratley S L, Hennet R J C. 1996. Chemical fixation of arsenic in contaminated soils. Appl Geochem 11: 633-643.

[24] Roussel C, Bril H, Fernandez A. 2000. Arsenic speciation: involvement in the evaluation of environmental impact caused by mine wastes. J Plant Nutr Soil Sci 29: 182-188.

[25] Taggart M A, Carlisle M, Pain D J, Williams R, Osbron D, Joyson A, Meharg A A. 2004. The distribution of arsenic in soils affected by the Aznalcóllar mine spill, SW Spain. Sci Total Environ 323: 137-152.

[26] Damodharan U, Reddy M V. 2014. Uptake of toxic trace metals and micro nutrients by sugarcane irrigated with treated effluents of sugar industry. Arch EnviromProt 1: 13-22.

[27] Simón M, Martín F, Ortiz I, García I, Fernández E, Fernández J, Dorronsoro C, Aguilar J. 2001 . Soil pollution by oxidation of tailings from toxic spill of a pyrite mine. Sci Total Environ 279, $63-74$. 
[28] Hooda P S, Alloway B J. 1994. Changes in operational fractions of trace metals in two soils during two-years of reaction time following sewage sludge treatment. Int J Environ Anal Chem57: 289-311.

[29] Roca M C, Vallejo V R. 1995. Effect of soil potassium and calcium on cesium and strontium uptake by plant roots. J Environ Radioact 28:141-159.

[30] Kabata-Pendias A, Pendias H. 2001. Trace elements in soils and plants (3rd ed., p. 413). New York: CRC.

[31] Rodriguez P B, Tome F V, Lozano J C. 2002. About the assumption of linearity in soil-to plant transfer factors for uranium and thorium isotopes and 226Ra. Sci Total Enviro 284: 167-175.

[32] Tome F V, Rodriguez M B, Lozano J C. 2003. Soil-to-plant transfer factors for natural radionuclides and stable elements in a Mediterranean area. J Environ Radioact 65: 161-175.

[33] Bunzl K, Albers B P, Schimmack W, Belli M, Ciuffo L, Menegon S. 2000. Examination of a relationship between 137Cs concentrations in soils and plants from alpine pastures. J Environ Radioact 48: 145-158.

[34] Barzegar A, Koochekzadeh A, Xing B S, Stephen H. 2005. Concentration changes of Cd, Ni and $\mathrm{Zn}$ in sugarcane cultivated soils. Water Air Soil Pollut 161: 97-112.

[35] Evans L J, Spiers G A, Zhao G. 1995. Chemical aspects of heavy metal solubility with reference to sewage sludge amended soils. Intern J Environ Anal Chem 59, 291-302.

[36] Chalabi A S A., Hawker D. 2000. Distribution of vehicular lead in road side soils of major roads of Brisbane, Australia. Water Air Soil Pollut 118: 299-310. 